\title{
Study of PLTMH development planning in Sasnek village Sawiat district, South Sorong regency West Papua province
}

\author{
Markus Dwiyanto Tobi, Vina N Van Harling \\ Saint Paul Catholic Polytechnic Sorong, Indonesia
}

\begin{abstract}
Article Info
ABSTRACT

Article history:

Received Sep 1, 2018

Revised Jul 7, 2019

Accepted Jul 21, 2019

\section{Keywords:}

Micro hydro

PLTMH

Power generation

Electricity is needed by the whole society. Sasnek village is one of the villages located in Sawiat District, South Sorong Regency, West Papua Province. Sasnek village is very clear and inhabited around 100KK. This village has not been served by electricity until now. Micro-hydro power plants are smallscale power plants whose capacity presents between $100 \mathrm{~W}$ to $100 \mathrm{~kW}$. This study will be used for loading stages with a 12 Volt DC power capacity, because it is one of the most efficient, young and safe ways. Measurement of air discharge, discharged by 2 liters/second from a measurement area of $5 \mathrm{~m} 2$ and an average air speed of $00.65 \mathrm{~m} / \mathrm{d}$. However, due to the condition of the river water flowing throughout the year in the sense of never dried, then used a correction factor of 0.75 . Thus the flow that can be used is equal to $0.65 \mathrm{~m} 3 / \mathrm{d}$. Based on the analysis of the potential contained in Sasnek PLTMH, it can be calculated Distribution Grid sourced from Sasnek PLTMH is $10 \mathrm{KW}$.With the careful planning so that the results of its implementation will give a positive impact to be meeting the needs of electricity in the village and surrounding villages sasnek.
\end{abstract}

Copyright $(0) 2020$ Institute of Advanced Engineering and Science. All rights reserved.

\section{Corresponding Author:}

Markus Dwiyanto Tobi,

Saint Paul Catholic Polytechnic Sorong,

J1. R.A Kartini No. 1 Kampung Baru, Indonesia.

Email: dwiyanto@poltekstpaul.ac.id

\section{INTRODUCTION}

\subsection{Background}

Electrical energy is energy that can not be separated from public life. Activities and needs of people in their daily life can not be separated by the absence of electricity. Indonesia is a country that has many potential sources of renewable energy which has not been utilized optimally. The potential of renewable energy has been utilized mostly in the form of its river water tends to be discharged into the sea. Yet every kilometer of the river can be used as a source of energy to drive the micro-hydro power plants.

This renewable energy utilization can be optimized, especially in rural locations or villages, which are generally spread and also not possible to get a service grid. Because it is necessary to do some business that is to build a separate sendri plant from grid. One is a micro-hydro power plants as one of the national energy alternatives.

Through the concept of micro-hydro "Power Pal System", people in the village in the province of West Papua who have not enjoyed electricity can be met. This is a major reason for the limited supply of electricity power can be overcome. For the utilization of hydroelectric power plants are divided into three categories: large, mini, and micro. There are no clear provisions regarding the division of the scale. It seems that each country has different rules. However, in general, water power (hydropower) large scale has a capacity of over $10 \mathrm{MW}$. Mini capacity of $200 \mathrm{~kW}$ to $10 \mathrm{MW}$, and micro capacity of up to $200 \mathrm{~kW}$ [1]. Hydropower potential in Indonesia is theoretically estimated to be around 75,000 MW spread over 1,315 locations. Hydropower is a potential source of energy which is very large, but its use is still far below its potential. And 
the potential is estimated at 34,000 MW, could be developed for power plants with a large enough capacity, $100 \mathrm{MW}[2]$.

Micro-Hydro Power Plant is one of the concepts of power plants that produced by small-scale hydropower [3]. Where through this concept, the water flow is slightly revised and meet the criteria of "Power Pal System" that will generate electricity, which then supply to consumers. The application of the concept of micro-hydro power, can be useful for people who live in the village and have a good enough water potential, thus providing a solution for the supply of electricity in the region. Through the concept of "power microhydro pal system ", people in the village who until now have not enjoyed minimal lighting or electricity can be met.

\subsection{Formulation of the problem}

Sasnek village is one of the villages located in Sawiat District, South Sorong Regency, West Papua Province. The village consists of $\pm 170 \mathrm{KK}$ and is one of the remote villages, which until now have not been able to enjoy the use of electricity. So often people in this village feel the unfairness of the policy electrify PLN in Papua, because until now the village could not be energized electrical power source PLN. Sasnek Village have three (3) waterfall flow sources, which basically have the capacity if used to generate electricity [4-5]. This is the main reason for researchers to be able to contribute knowledge by conducting studies and studies on the development of PLTMH in the Sasnek village, Sawiat District South Sorong Regency, West Papua Province. The results of this study will be used as the material implementation of PLTMH development in the village. This study will assess the maximum limit,

\subsection{Purpose and objectives}

The purpose and objective of this study is to study planning in setting up a system of electrical energy by utilizing the potential water energy available in Sasnek Village, located in the Sawiat District, South Sorong Regency, West Papua Province. So that in the future implementation of the PLTMH construction, can provide direct benefits to the village Sasnek, in order to increase economic productivity and the survival of the Sasnek village communities.

\section{THE PURPOSED METHOD}

The method used in this study is the measurement of water flow [6], by measuring the river surface area, and the speed of the river flow. To obtain the area can be calculated using the following formula:

$$
X_{\text {average }}=\frac{\sum x}{n}
$$

So that

$$
A(\text { Area })=X_{\text {average }} \times L
$$

Whereas for river speed measurement (v), previously calculated the average travel time with the formula as follows:

$$
t_{\text {average }}=\frac{\sum t}{n}
$$

so $\mathrm{v}$ is obtained: $\left(\mathrm{t}_{0}-\mathrm{t}_{1}\right)$

$$
v=\frac{s}{t_{\text {average }}}
$$

Where $s$ is the distance of the river.

After the area and speed of the river are known, the amount of discharge in the river is calculated by the following formula:

$$
Q=A x V\left(m^{3} / \text { sekon }\right)
$$

While to increase the electrical power produced by the MHP in this study the researchers used the method of increasing head height. The application is by damming the upstream of the river by building a small dam, so that the total fall height (head) of the plant installation system can be increased, and how much the height of the fall (head) can be increased depending on the size and height of the dam that was built. 


\section{RESEARCH METHOD}

3.1. Stages Research

Stages performed in this study is described in the flowchart in Figure 1.

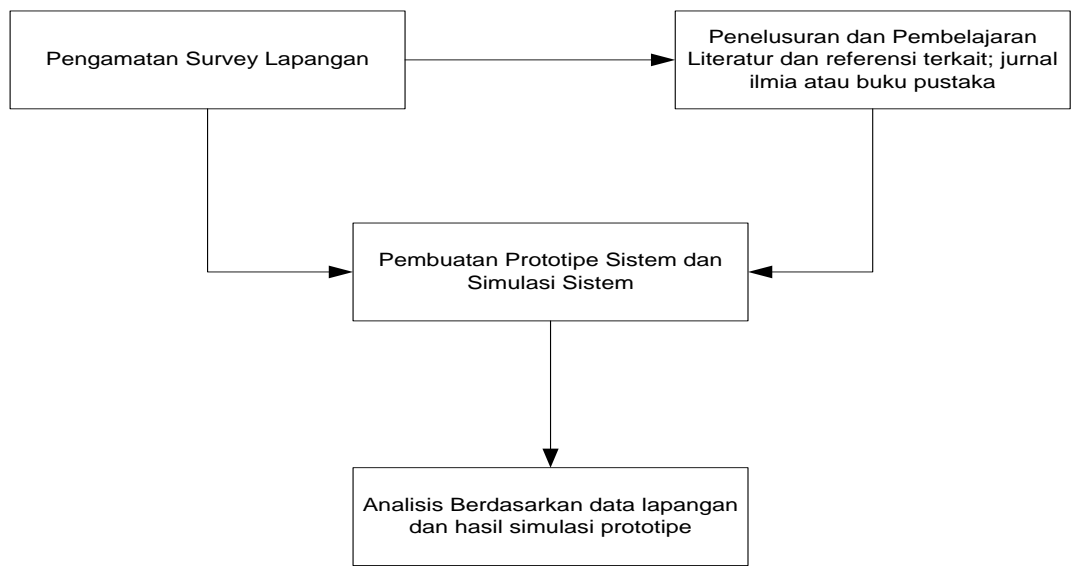

Figure 1. Flow Research

\subsection{Research sites}

The location of this research take place Sasnek Village Sawiat District South Sorong Regency, West Papua Province, where this village has a number of about $170 \mathrm{kk}$.

\subsection{Prototype Design of PLTMH}

The following design prototype design of PLTMH shown in Figure 2.

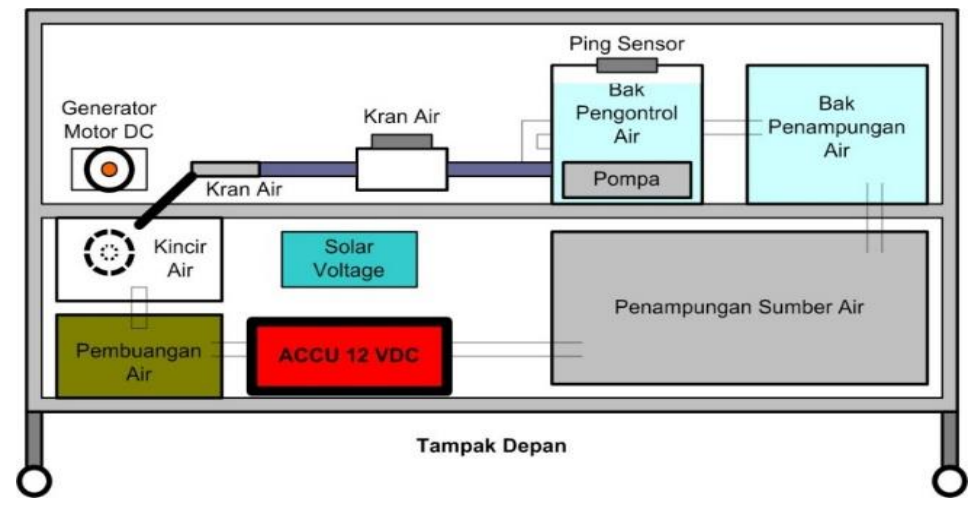

Figure 2. The design of the prototype design for PLTMH

To design the prototype of PLTMH used as a water pump pressure (like a waterfall), water as a source of energy, turbine and dynamo DC. Following the steps of the design of the prototype [7-9].

\subsubsection{Design Layout}

Design the location or position of pumps, turbines, DC motors, batteries, inverter and the load. Board modules that will be used as a place to put circuits made of mica and iron measuring $3 \times 3$. The size of the mica board as a series laying container and iron box as a frame work table is as follows:

Table of iron box

Long Boards Mika

Width Boards Mika

high Board Mica

$$
\begin{aligned}
& =50 \times 100 \mathrm{~cm} \\
& =100 \times 50 \mathrm{~cm} \\
& =50 \times 100 \mathrm{~cm} \\
& =100 \mathrm{~cm}
\end{aligned}
$$




\subsubsection{Design Place}

The design of the prototype container is made in two parts in the form of boxes/cabinets, namely [10-15]:

Block I / Floors 1: Consists of Bak precipitator, Valae control 1, the channel carrier, Valve control 2, like tranquilizers, rapid pipe (penstock), DC 12 Volt alternator dynamo, arduino control system and the motor driver, as well as the height of the sensor measuring circuit water level.

Block II / 2: Sump water, aquarium pump engines, Accu, dap pump turbine engines and auxiliary motor.

For the control circuit will be installed separately on a module using mica, the control circuit, shown in Figure 3, consists of the components of the electrical panel.

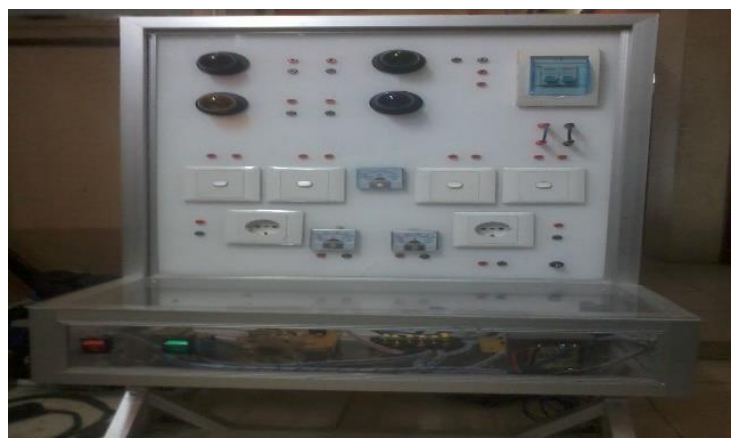

Figure 3. Control circuit

\section{RESULT AND DISCUSSION}

\subsection{Regional Placement Location}

Locations PLTMH being on the river, located in the village Sasnek Sasnek, PLTMH Sasnek obtained by utilizing the height difference (head) and flow rates of the river, where the river sasnek River is one of the region Kampung Sasnek, Sawiat District.

\subsection{Socio-Economic Conditions}

\subsubsection{Community Livelihood}

Livelihood of the people can be divided into two groups of people living in the capital districts and communities living around the suburban capital of the district. People living around the capital, in general there who worked as a civil servant, seasonal traders and fishermen. While people living in rural areas in general, farmers, ranchers, fishermen etc. The average income of people who work as farmers and ranchers and nelayanper average day 100,000, - 250,000 per household, while others variation according to their own profession.

\subsubsection{Infrastructure Condition}

The area of infrastructure development in the District Sawiat, as indicated by the increase in people's houses, besides followed by the development of supporting facilities such as road repairs and so forth. It occurs significantly after the establishment of the District Sawiat.

\subsubsection{Electrification Conditions}

Eletrifikasi conditions in the study area until time the electricity is not yet available permanen. As for electrity in the study area only from the generator (genset) and Solar Cells owned by individuals or groups scarecrow / specific oraganisasi. It cause meeting electricity needs in the study area is the main requirement, which until now has not been perceived by the public. The existence of the electrical energy produced by the generator are individually owned experiencing problems in operation, otherwise it will not be able to operate for 24 hours, the high price of fuel oil in the region, reaching Rp. 22,000, - 25,000 per liter, is a major obstacle to the electrification conditions in this region, in addition to the issue of accessibility.

\subsection{Hydraulic Potential and Plant Capacity}

\subsubsection{Water Discharge Measurement}

The area around the location of the PLTMH are in areas that have a fairly high level of rainfall [16]. Additionally, supported by the local community information that existing river flows throughout the year, so that the availability of water is maintained. To find out how big the river flow measurements [17-19]. The first 
step is to choose the location of the measurement taking into account the criteria for discharge measurements, once the location of the measurement followed by measurement of river water discharge.

\subsubsection{Different High Measurement}

The height difference is measured by using a Handheld Level and Analog Altimeter which has a high accuracy rate. Head count of the water level in the tub recana tranquilizers (forebay) to the level of water in the home plan generator (power house), the importance of the size of the head is 3 meters.

\subsubsection{Hydraulic Potential}

Hydraulic potential is the potential energy generated by water pressure due to gravity. Micro-hydro energy potential available in nature is a hydraulic potential $(\mathrm{Ph})$ in the form of potential energy. The amount is determined by the hydraulic potential of the discharge $(\mathrm{Q})$ and a height / tilt sutau river or head $(\mathrm{H})$. Mathematically can be described in the equation:

$$
\mathrm{Ph}=\mathrm{gx} \mathrm{Q} \times \mathrm{H}
$$

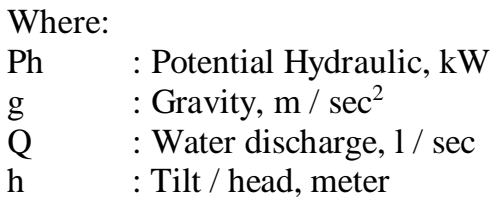

\subsubsection{Power Generating Capacity}

Not all the energy held in the form of hydraulic potential can be converted into electricity. At the time of the conversion of potential energy into electrical energy part of the energy will be lost as losess. In addition the amount of energy that can be obtained depends on the magnitude of the efficiency of turbine and generator that can be used. However, as a simple baseline power capacity can be calculated by the following equation:

$$
\mathrm{Pel}=\eta \mathrm{tPh}
$$

Where:

pill : power capacity revault, $\mathrm{kW}$

$\mathrm{Ph} \quad$ : Potential hydraulic, $\mathrm{kW}$

nt : The total efficiency, $\%$

nt price was set at $76 \%$ is taken from the theory losess on PLTMH. Thus the results of the initial calculation of PLTMH Sawiat power capacity can be seen in the Table 1.

Table 1. Power Capacity Estimation PLTMH Sasnek Village

\begin{tabular}{clccc}
\hline No & Parameter & Symbol & Unit & Value \\
\hline 1. & debit & $\mathrm{Q}$ & Liter / Sec & 2 \\
2. & Head & $\mathrm{H}$ & meter & 3 \\
3. & gravitation & $\mathrm{G}$ & Meter / detik2 & 9.8 \\
4. & efficiency Total & $\mathrm{T}$ & $\%$ & $75 \%$ \\
5. & Power capacity & pill & $\mathrm{kw}$ & 10,000 \\
\hline
\end{tabular}

\subsection{Facility Design}

\subsubsection{Plans Weir (Weir)}

Dam is part of the civil construction built spanning the river that serves to raise the level of air. Bendung also functions as a regulator of the amount of water needed generators.

Dam building equipped with wings and door drain to clean sediment which accumulates in the bottom of the weir. The forces into consideration in the design of the weir is grinding style, the style press downward, gravity, seismic force, power sliding and hydrostatic force.

\subsubsection{Tapper Channel Plan (Intake)}

Tapper channel known as the intake structure is a building made of stone foundation partner in plaster with a wide rectangulardengan form in accordance with the needs of the water used.

If the condition of the dammed river water is very much rubbish then this building must be equipped with a filter made of steel strip or begel which will serve to filter or filters. Intake can be built on the left or 
right of the weir building known as the intake side or in front of the dam is called direct intake. Intake structure using stone masonry construction times (1:3) with cement plaster.

Trashrack intake structure equipped with a series of plate-shaped iron bars as a buffer and filter junk fiber objects that are not expected to carry over with the flow of water.

\subsubsection{Bearer Channel Plan (Headrace)}

Design lay-out of PLTMH equipped with bearer channel that carries water into the forebay. But in this design uses only as a penstock to the turbine inlet.

\subsubsection{Soothing Body Plan (Forebay)}

Like a sedative is located near the weir building. Structures like tranquilizers such as masonry times (1: 3) consists of a settling basin (setting basin), spillway (spillway), tranquilizers trashrack and tub [20-23].

The building is commonly known as head tank that serves as a water reservoir located on the top side to flow into the turbine unit which is located at the bottom. The height difference between the water fall is known as the Head.

Bak sedative serves to control the flow of water in the pipe rapidly in the event of load fluctuations, soothing water flow before entering into the pipe rapidly, but it is also as the last screening of trash and sediment solid particles from entering the turbine.

The plan on the PLTMH Sasnek Calming Bath facility in design as well as Bak precipitator with kapasitas 20 - 50 liters / sec.

\subsubsection{Rapid Plumbing Plan (Penstock)}

Rapid pipe is pressurized pipe that connects the turbine inlet sedative like. The material to be used as a penstock at Sawiat PLTMH is PVC. Factors that should be considered in the design of the penstock is pressure, pipe diameter, thickness, weight and ease of mobilization pipe [24-26]. The parameters necessary to determine rapidly the pipe diameter is: water flow, head, pipe length and the average angle of the pipe.

Having in mind these parameters then using the results of the data output can be determined optimum flow velocity in the pipe, then the pipe diameter and weight rapidly can be calculated.

The Rapid Pipe Length (penstock) for PLTMH Sasnek is 100 meters measured from like sedative Turbine with diameter penstock 8".

\subsubsection{House Plan Generator (Power House)}

Home generator in micro hydro schemes designed to protect the mechanical-electrical equipment such as turbines, generators and electronic control equipment on climate change in addition to the home station should also provide space and comfort for the operator. In addition the bottom floor of the house generator connected to sewers (tailrace) towards the river. Position floor of the house plants are at a considerable height from the base tailrace [27-30].

PLTMH plants home layout plan Sasnek is house-type plants on the ground or in the ground with a size of $4 \times 8$ meters. The foundation is designed for Cross Flow Turbine therefore storey house plants castings reinforced with reinforced concrete structure. As for the construction of buildings in the form of masonry with cement plaster. House building plant is also equipped with sewer (tailrace) along 20-50 meters with a size of 1 $\mathrm{x} 1$ meter.

\subsection{Hardware Design Mechanical-Electrical}

The equipment included in the mechanical-electrical components on the PLTMH is Turbine, Generator and Control System / Security.

\subsubsection{Turbine Plans}

Based on the results of design and calculations for the scheme PLTMH Sasnek turbines proposed for use is Turbine Crossflow T-14 D 400 which is a local product (Sorong, Papua) with turbine efficiency reached $0.75 \%$, the shaft speed $2500 \mathrm{rpm}$ and the power of the turbine shaft $50 \mathrm{Kw}$ move generator with an output of $10 \mathrm{~kW}, 220 \mathrm{~V}, 50 \mathrm{~Hz}$, the maximum condition. In this turbine consists of: Base frame, Inlet Valve, Hang Regulator and Rotor (Runner). Base frame made of Mild Steel, Profiles "U", equipped with armature planted in the foundation and open-flume to direct wastewater into waterways [31-34].

Turbine housing are made of mild steel, iron plate with a certain thickness so that a sturdy turbine construction. Rotor (runner) made of iron FCD, on the left and right side bearing placed runner attached to the turbine. Turbines in use for PLTMH Sasnek shown in Figure 4. Power capacity calculation results PLTMH Sasnek South Sorong regency based on survey results detail can be seen on Table 2. 


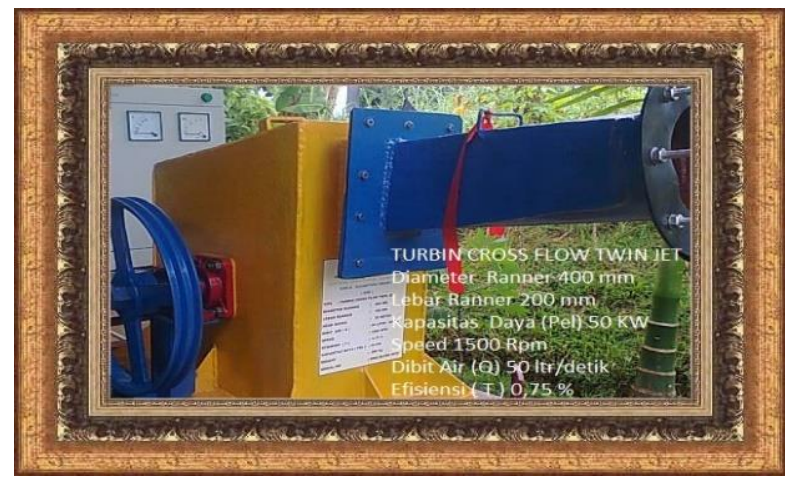

Figure 4. Turbines in use for PLTMH Sasnek

Table 2. Power Capacity Calculation Results PLTMH Sasnek South Sorong Regency Based on Survey

\begin{tabular}{lccc}
\multicolumn{1}{c}{ Results Detail } & & Unit \\
\hline Purbine type & Symbol & Value & - \\
Type & crossflow & & - \\
debit design & $\mathrm{T}-14$ & & liters / sec \\
Head & $\mathrm{Q}$ & 20 & $\mathrm{M}$ \\
diameter Runner & $\mathrm{H}$ & 3 & $\mathrm{~mm}$ \\
unit Debit & $\mathrm{D}$ & 400 & $1 / \mathrm{sec}$ \\
Speed unit & Qmax & $20-100$ & - \\
Runner width, mm & & & $\mathrm{mm}$ \\
Turbine Speed & & 200 & $\mathrm{rpm}$ \\
Turbine efficiency & $\mathrm{N}$ & 1500 & Fraction \\
Mechanical Transmission Efficiency & Ntur & 0.75 & Fraction \\
efficiency Generator & Ntrm & 0.95 & Fraction \\
Hydraulic potential & Ngen & 0.9 & $\mathrm{~kW}$ \\
Turbine Power Capacity & Ph & 3 & $\mathrm{~kW}$ \\
Power Capacity Generator & Ptur & 50 & $\mathrm{~kW}$ \\
\hline
\end{tabular}

(See Appendix: TURBINE SPECIFICATIONS: crossflow T-14 D400)

\subsubsection{Generator Plan}

At PLTMH Sasnek rotation of the turbine shaft from the calculation of the flow of water is 2 liters/sec, while the rotation needed a generator to produce electrical power is $1500 \mathrm{rpm}$ then by way increases the flow rate of discharge and the volume of water required body mounting container reserves by raising capacity his shelter. PLTMH Sasnek shaped mechanical transmission pulley with appropriate diameter ratio associated with V-Belt [35-38].

As for the technical specifications of the PLTMH Generator Sasnek is: 1-phase AC Synchronous Generator $220 \mathrm{~V}, 50 \mathrm{~Hz} 1500 \mathrm{rpm}$, the power factor of 1 x $10 \mathrm{~kW}$, generator capacity of $10 \mathrm{~kW}$. The planned form of the generator shown in Figure 5.

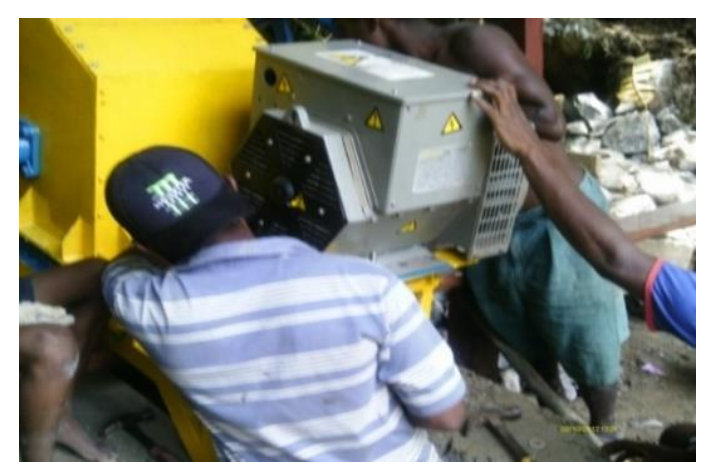

Figure 5. Plan Form Generator 


\subsubsection{Control Systems Plan and Security}

Remember about location of PLTMH Sasnek in remote areas, so control system used type of Electronic Load Controller (ELC). With this system load fluctuations will be set and adjusted automatically by the ELC. The construction work of unit PLTMH Sasnek South Sorong Regency can be seen on Tables 3 to 5 .

Table 3. Technical Specifications of Work Plan Transmission Construction Work One (1) Unit Pltmh Sasnek

\begin{tabular}{ll}
\multicolumn{2}{c}{ South Sorong Regency } \\
\hline \multicolumn{2}{c}{ Transmission network } \\
\hline Length Network & 3000 meters \\
Tension & 220 Volt \\
Type / Size Cable & Tic Cables 2 x 70 mm \\
Type Column & Iron (Standard Network JTM) \\
Number of Poles & 300 Trunk \\
Accesorries & SPLN \\
Grounding/ Earthing & SPLN \\
\hline
\end{tabular}

Table 4. Technical Specifications of Turbines Plan to be in Use Construction Work One Unit Pltmh Sasnek

\begin{tabular}{ll}
\multicolumn{2}{c}{ South Sorong Regency } \\
\hline \multicolumn{2}{c}{ Turbine } \\
\hline Type & Crossflow T-14 D 300 \\
Power & $50 \mathrm{~kW}$ \\
Speed Unit & 38.00 \\
Head Gross & 3 meters \\
Water discharge Optimum & $20-100$ liters / sec \\
Turbine Speed & $2500 \mathrm{rpm}$ \\
Efficiency & 0.75 \\
\hline
\end{tabular}

Table 5. Technical Specifications of Generator Plans, and Transmission Control System Mechanical Construction Work One Unit Sasnek Pltmh-Sawiat South Sorong Regency

\begin{tabular}{|c|c|c|}
\hline \multicolumn{3}{|c|}{ Generator } \\
\hline Type & \multicolumn{2}{|c|}{ AC Sync 1 Phase } \\
\hline Power rating & \multicolumn{2}{|c|}{$1 \times 10 \mathrm{~kW}$} \\
\hline Frequency & \multicolumn{2}{|c|}{$50 \mathrm{~Hz}$} \\
\hline AVR & \multicolumn{2}{|c|}{ Standard } \\
\hline Phase / Pole & \multicolumn{2}{|c|}{1 Phase } \\
\hline Shaft Speed & \multicolumn{2}{|c|}{$1500 \mathrm{rpm}$} \\
\hline Tension & \multicolumn{2}{|c|}{220 Volt } \\
\hline Power factor & \multicolumn{2}{|c|}{0.8 Frasi } \\
\hline Efficiency & \multicolumn{2}{|l|}{0.9} \\
\hline \multicolumn{3}{|c|}{ Control system } \\
\hline Type & \multicolumn{2}{|c|}{ ELC } \\
\hline Power rating & \multicolumn{2}{|c|}{$10 \mathrm{~kW}$} \\
\hline Tension & \multicolumn{2}{|c|}{220 Volt } \\
\hline \multicolumn{3}{|c|}{ Mechanical transmission } \\
\hline \multicolumn{3}{|c|}{ Round Axis Turbine } \\
\hline \multirow{2}{*}{\multicolumn{2}{|c|}{ Round Shaft Generator }} & $1500 \mathrm{rpm}$ \\
\hline & \multicolumn{2}{|c|}{ Pulley ratio } \\
\hline \multicolumn{3}{|l|}{ Type / Type Belt } \\
\hline
\end{tabular}

\subsection{Transmission Network Design}

The main parameters in the design of the transmission network on micro-hydro plant is to determine network length, a large voltage (low voltage network or medium voltage network JTR JTM), the type and size of cable, pole type (iron), high mast and pole number [39-42]. PLTMH Sasnek transmission network for use Medium Voltage Networks (JTM) 240v along 3000 meters.

Cables used type of aluminum with a conductance (resistance) at $36.72 \mathrm{MS} / \mathrm{m}$ supported by iron pillars (Standard JTM - PLN) with a height of 12 meters as much as \pm 300 rods. 


\subsection{Budget Plan for Rehabilitation PLTMH Sasnek}

The budget forecasts for the cost of development of PLTMH activities Sasnek, Sawiat District, South Sorong regency amounted 2.370.046.000.00, Budget Plans is calculated based on the economic conditions in 2016, data is taken from the Basic Price Material issued by the Government of South Sorong Regency in 2016.

For the record the cost of development of PLTMH Sasnek Sawiat District in South Sorong regency due to accessibility goods / services in this region can only be achieved by means of land transportation and marine.

\section{CONCLUSION}

After the measurement of water discharge, discharge obtained at 2 liters / second of the measurement area $5 \mathrm{~m} 2$ and average water velocity $00.65 \mathrm{~m} / \mathrm{d}$. However, due to the condition of the river water flowing throughout the year in the sense of never dried, then used a correction factor of 0.75 . Thus the flow that can be used is equal to $0.65 \mathrm{~m} 3 / \mathrm{d}$.

Based on the analysis of the potential contained in Sasnek PLTMH, it can be calculated Distribution Grid sourced from Sasnek PLTMH is $10 \mathrm{KW}$.

\section{REFERENCES}

[1] Effendy, Machmud. "Design of Induction Motor And Generator (Misg) In Microhydro Power Plants. " Transmission, vol. 11, no. 2, 28 Mar. 2012, pp. 71-76.

[2] Mahalla, Mahalla, Suharyanto Suharyanto, and M. Isnaeni. "IMAG Performance Evaluation on Cokro Tulung Micro Hydro Power Station in Klaten Regency." National Journal of Electrical Engineering and Information Technology 2.1 (2013): 72-77.

[3] Napitupulu Janter. "Mini Hydro Power Plant (micro power plants) in the Management of Green Energy." Journal DA, Department of Electrical Engineering University of Darma Great Medan. 2012: JDA 21-25.

[4] Tobi, Markus Dwiyanto. "Optimization Effect of Power Transformer Feeder for Development Expenses, Minimizing the Disruption and Deficit in The Electricity Charges Ow-West Papua." Electro Luceat. 2017. Vol 3. (1): 10-18.

[5] Tobi, Markus Dwiyanto, and Vina N. Van Harling. "Analysis of Experiment Characteristics Of Zero-Load 1 Phase Induction Generators." Electro Luceat, 5.1 (2019): 12-22.

[6] Setyo Putro Yogi Suryo, Tri Sudarsono Pitojo, Hadi Wicaksono Prima. "Planning Studies Micro Hydro Power $(\mathrm{PLTMH})$ on the river tumbles Village Atei Atei Sanamang Mantikai Katingan District of Central Kalimantan Province." Scientific Journal of UB. 2012. Vol 48 (2): 24-35.

[7] Al-Ogaili, Ali Saadon, et al. "Design and Experimental Results of Universal Electric Vehicle Charger Using DSP." TELKOMNIKA (Telecommunication, Computing, Electronics and Control), 16.4 (2018): 1435-1444.

[8] Wahyono, Tulus Djoko. "Design and manufacture of MHP synchronization tool panels with PLN low voltage networks". Diss Gadjah Mada University, 2008.

[9] Warsino, S. "Preliminary Study of Mechanical and Electrical System Design Power mini-hydro". National Seminar, Department of Electrical Engineering Faculty of Industrial Engineering Semarang Sultan Agung Islamic University. 2008.

[10] Arindya, Radita. "A Variable Speed Wind Generation System Based on Doubly Fed Induction Generator." Bulletin of Electrical Engineering and Informatics (BEEI), 2.4 (2013): 272-277.

[11] Daryabad, Habib. "Investigating the Effect of Demand Side Management on the Power System Reliability." Bulletin of Electrical Engineering and Informatics (BEEI), 4.2 (2015): 96-102.

[12] Razali, Nur Farhana Mohd, et al. "Electrical characteristic of photovoltaic thermal collector with water-multiwalled carbon nanotube nanofluid flow." Indonesian Journal of Electrical Engineering and Computer Science (IJEECS), 13.1 (2019): 324-330.

[13] Rukman, Nurul Shahirah Binti, et al. "Electrical and thermal efficiency of air-based photovoltaic thermal (PVT) systems: An overview." Indonesian Journal of Electrical Engineering and Computer Science (IJEECS), 14.3 (2019): 1134-1140.

[14] Setiadi, Herlambang, and Karl O. Jones. "Power system design using firefly algorithm for dynamic stability enhancement." Indonesian Journal of Electrical Engineering and Computer Science (JEECS), 1.3 (2016): 446-455.

[15] Kamil Haval Sardar, Said Dalila Mat, Mustafa Mohd Wazir, Miveh Mohammad Reza, Ahmad Nasarudin. "Lowvoltage ride-through for a three-phase four-leg photovoltaic system using SRFPI control strategy". International Journal of Electrical and Computer Engineering (IJECE), 9.3 (2019): pp. 1524-1530.

[16] Sugiri, Agus, and A. Yudi Eka Risano. "Study of Potential Micro Hydro Power Plant (PLTMH) in Cikawat River, Talang Mulia Village, Padang Cermin District, Pesawaran Regency, Lampung Province." Mechanical Engineering Scientific Journal 1.1 (2013).

[17] Parabelem TDR 2011. "Analysis of micro hydro power plant (PLTMH) At Watershed Ongkak In the village Muntoi Mongondow Mongondow Bolaang”. Research Journal Saintek. 2011 Vol. 16 (2): 160-171. 
[18] Shneen Salam Waley. "Advanced Optimal For Three Phase Rectifier in Power Electronic System". Indonesian Journal of Electrical Engineering and Computer Science (IJEECS), 11.3 (2018): pp. 821-830.

[19] M-Dawam, Siti Rafidah. Ku-Mahamud Ku Ruhana. "Reservoir water level forecasting using normalization and multiple regression”. Indonesian Journal of Electrical Engineering and Computer Science (IJEECS), 14.1 (2019): pp. 443-449.

[20] Sukamta Sri, Kusmantoro Adhi. "Planning Micro Hydro Power (PLTMH) Jantur Tabalas East Kalimantan.” Journal of Electrical Engineering, State University of Semarang. 2013. Vol 5 (2): 58-63.

[21] Jayaraju Gaddala, Rao Gudapati Sambasiva. "Intelligent controllerbased power quality improvement of microgridintegration of photovoltaic power system using new cascade multilevel inverter". International Journal of Electrical and Computer Engineering (IJECE). 9.3 (2019): pp. 1514-1523.

[22] R. Palanisamy, K. Vijayakumar, V. Venkatachalam, R. Mano Narayanan, D. Saravanakumar, K. Saravana. "Simulation of various DC-DC converters for photovoltaic system". International Journal of Electrical and Computer Engineering (IJECE), 9.2 (2019): pp. 917-925.

[23] Abdullah Aziera, Yusoff Siti Hajar, Zaini Syasya Azra, Midi Nur Shahida, Mohamad Sarah Yasmin. "Energy efficient smart street light for smart city using sensors and controller" Bulletin of Electrical Engineering and Informatics (BEEI), 8.2 (2019): pp. 558-568.

[24] Suparyawan, D. P. D., I. N. S. Kumara, and Wayan G. Ariastina. "Microhydro Power Plant Planning Study in Sambangan Village, Buleleng Regency, Bali." Electrical Technology Scientific Magazine 12.2 (2013).

[25] Kamalakkannan S., Kirubakaran D. "Solar energy based impedance-source inverter for grid system". International Journal of Electrical and Computer Engineering (IJECE), 9.1 (2019): pp. 102-108.

[26] Gutowski, Timothy, Jeffrey Dahmus, and Alex Thiriez. "Electrical energy requirements for manufacturing processes." 13th CIRP international conference on life cycle engineering. Vol. 31. No. 1. CIRP International Leuven, Belgium, 2006.

[27] Hanmandlu, M., and Himani Goyal. "Proposing a new advanced control technique for micro hydro power plants." International Journal of Electrical Power \& Energy Systems, 30.4 (2008): 272-282.

[28] Halim Mohd Firdaus Mohd Ab, Yaakub Muhamad Faizal, Harun Mohamad Haniff, Annuar Khalil Azha Mohd, Basar Farriz $\mathrm{Hj} \mathrm{Md}$, Omar Mohd Nazri. "An analysis of energy saving through delamping method" International Journal of Electrical and Computer Engineering (IJECE), 9.3. (2019): pp. 1569-1575.

[29] Samal Sarita, Hota Prakash Kumar. "Wind Energy Fed UPQC System for Power Quality Improvement". Bulletin of Electrical Engineering and Informatics (BEEI), 7.3 (2018): pp. 495-504.

[30] Fudholi Ahmad, Musthafa Mariyam Fazleena, Ridwan Abrar, Yendra Rado, Desvina Ari Pani, Rahmadeni, Tri Suyono, Sopia Kamaruzzaman. "Energy and exergy analysis of air based photovoltaic thermal (PVT) collector : a review". International Journal of Electrical and Computer Engineering (IJECE), 9.1 (2019): pp. 109-117.

[31] Ogayar, B., P. G. Vidal, and J. C. Hernandez. "Analysis of the cost for the refurbishment of small hydropower plants." Renewable Energy, 34.11 (2009): 2501-2509.

[32] Dawoud, Samir M., Xiangning Lin, and Merfat I. Okba. "Hybrid renewable microgrid optimization techniques: A review." Renewable and Sustainable Energy Reviews, 82 (2018): 2039-2052.

[33] Shaaban, Mohamed, Hossein Zeynal, and Khalid Nor. "MILP-based short-term thermal unit commitment and hydrothermal scheduling including cascaded reservoirs and fuel constraints." International Journal of Electrical \& Computer Engineering (IJECE), (2088-8708) 9 (2019).

[34] Md. Asaduz-Zaman,Md. Habibur Rahaman,Md. Selim Reza, Md. Mafizul Islam. "Coordinated Control of Interconnected Microgrid and Energy Storage System" International Journal of Electrical and Computer Engineering (IJECE), 8.6 (2018):pp. 4781-4789.

[35] Wibawa, Unggul, Hari Santoso, and I. G. A. Dharmayana. "Design of Micro Hydro Power Plant (PLTMH) Bendosari Village, Pujon District, Malang Regency" Electrical Journal of Unika Atma Jaya 7.1 (2014): 45-58.

[36] Kudithi, Nageswara Rao, and Sakda Somkun. "Power flow management of triple active bridge for fuel cell applications School of Renewable Energy and Smart Grid Technology" International Journal of Power Electronics and Drive System (IJPEDS), 10.2 (2019): pp. 672-681.

[37] Al-Jumaili, Mustafa Hamid, Ahmed Subhi Abdalkafor, and Mohammed Qasim Taha. "Analysis of the hard and soft shading impact on photovoltaic module performance using solar module tester." International Journal of Power Electronics and Drive System (IJPEDS). 10.2 (2019): pp. 1014-1021.

[38] A. Mezouari1, R. Elgouri, M. Igouzal, M. Alareqi, K. Mateur, H. Dahou, L. Hlou. "New Photovoltaic Energy Sharing System between Homes in Standalone Areas". International Journal of Electrical and Computer Engineering (IJECE), 8.6 (2018): pp. 4855-4862.

[39] Sekhar G. G. Raja. Banakar Basavaraja. "Solar PV fed non-isolated DC-DC converter for BLDC motor drive with speed control" Indonesian Journal of Electrical Engineering and Computer Science (IJEECS), 13.1 (2019): pp. 313-323.

[40] Sule Luther, Rompas Parabelem Tinno Dolf. "Oscillating wave energy power generator for lift net fishing boat" Indonesian Journal of Electrical Engineering and Computer Science (IJEECS), 13.1 (2019): pp. 354-360.

[41] Bouderbala Manale, Bossoufi Badre, Lagrioui Ahmed, Taoussi Mohammed, Aroussi Hala Alami, Ihedrane Yasmine. "Direct and indirect vector control of a doubly fed inductiongenerator based in a wind energy conversion system". International Journal of Electrical and Computer Engineering (IJECE), 9.3 (2018): pp. 1531-1540.

[42] Kumar Arvind, Alam Bashir "Energy harvesting earliest deadline first scheduling algorithm for increasing lifetime of real time systems". International Journal of Electrical and Computer Engineering (IJECE), 9.1 (2019): pp. 539-545. 